American Journal of Immunology 1 (1): 48-54, 2005

ISSN 1553-619X

(C) 2005 Science Publications

\title{
Androgen Receptor in Macrophages of Male Rat is Greater Than in Female
}

\author{
${ }^{1}$ Kazem Ahmadi and ${ }^{2}$ Alan B. McCruden \\ ${ }^{1}$ Department of Immunology, Faculty of Medicine and Research Centre of Molecular Biology \\ Baqiyatallah Medical Science University \\ ${ }^{2}$ Department of Immunology, University of Strathclyde, Glasgow, G4 ONR, UK
}

\begin{abstract}
The presence and possible sex differences of androgen receptor in peritoneal macrophages was investigated using immunomagnetic beads. Macrophages were incubated with different concentrations of $\left[{ }^{3} \mathrm{H}\right]-5 \alpha \mathrm{DHT}$ in the presence or absence of a 100 fold excess of unlabelled $5 \alpha$-DHT. Labelled cells were separated from unbound steroid by immunomagnetic beads coated with anti-rat macrophage antibody. The binding identified in the rat macrophages was highly selective towards androgenic compounds. The dissociation constant $(\mathrm{kd})$ value for the receptor was calculated to be $3.3 \times 10^{-9} \mathrm{M}$ and $5 \times 10^{-9} \mathrm{M}$ for macrophages of male and female rat respectively. The number of receptors in each cell was $792 \pm 3$ and $120 \pm 1$ for male and female respectively. Indicating a sex differences in androgen receptor $(\mathrm{p}<0.001)$. Taken together it can be concluded that part of sex differences in immune responses and also auto-immune disease could be related to sex differences in androgen receptor in macrophages.
\end{abstract}

Key words: Macrophage androgen receptor, immunomagnetic, male and female

\section{INTRODUCTION}

The macrophage system has emerged as cell playing a central role in the overall immune reaction in host defence, as well as expression of immune based chronic inflammatory disease ${ }^{[1,2]}$. Macrophages are distributed in large numbers throughout the body, responding to various stimuli in a number of different ways which include secretion of some hundred different substances $^{[3-6]}$ which in turn enhance, suppress or modulate the other cell types involved in the immune response.

Sex steroid receptors have been found in many lymphoid tissues and cells ${ }^{[7-9]}$. The reticuloendothelial cells of the thymus have been reported to contain receptors for estradiol, dihydrotestosterone, progesterone and cortisol while the reticuloendothelial cells of the bursa have been shown to have receptor for estradiol, dihydrotestosterone and progesterone ${ }^{[10]}$. Many attempts have been made to discover sex steroid receptors in other immune cells, leading to the discovery of such receptors in some of the cell subsets while not in others. This gave some indication of how these steroids might regulate the immune response by selectively acting on some cells ${ }^{[11,12]}$. Receptors for estrogens have also been reported in human peripheral blood mononuclear cells ${ }^{[13]}$ and in macrophages ${ }^{[14,15]}$. Receptors for androgen has also been reported in human peripheral leukocyte containing 70-80\% Tlymphocytes, 5\% B-lymphocytes, about 10-25\% monocytes and some dendritic cells ${ }^{[16]}$.
The possible presence of sex steroid receptors on the antigen-presenting cells, was suggested by Stumpf, in $1976^{[17]}$. After that, it was suggested that sex hormones may influence the presentation of antigen and production of important cytokines ${ }^{[18-26]}$. This theory was later supported by the finding of estrogen receptor on macrophages $^{[14]}$ and androgen receptor on macrophage like synoviocyte ${ }^{[27]}$. Further evidence is provided by observation made by Mizuno et al. ${ }^{[28]}$ who reported the identification of androgen receptor in mouse osteoclastlike multinucleated cells. Baranao et al. ${ }^{[29]}$ demonstrated that female sex hormones regulate the macrophage function, thus both decrease or absence of these steroids leads to impaired function of cells. It is suggested that sex steroid hormone may also play a pivotal role in the regulation of the activity of surface receptors involved in phagocytosis ${ }^{[30,31]}$.

Now a significant difference between the immune systems of the male and the female has been accepted $[7,32,33]$. The immune reactivity is regarded to be greater in females than males and there is also a greater incidence of auto immune disease in females ${ }^{[32,33]}$. Female have higher immunoglobulin levels, stronger immune responses, reduced incidence of tumours and greater resistance to a variety of bacterial, viral and parasitic infections ${ }^{[34,35]}$. Females also have a much greater susceptibility to immune disease $^{[33,36]}$. For example, the ratios of female to male susceptibility to SLE and RA are 9:1 and 4:1, respectively ${ }^{[37]}$. 
Macrophages are believed to possess many immunoregulatory functions and steroid hormones have been shown to have numerous effects on the macrophage ${ }^{[24,38,39]}$. Thus, many of the male/female immune differences could be due partly to the effects of selected sex hormones acting selectively on the macrophage ${ }^{[40,41]}$. Other studies have stabilised that sex hormones directly or indirectly affect $\mathrm{T}, \mathrm{B}$ and macrophages by manipulating the production of lymphokines and cytokines ${ }^{[42]}$.

This project was designed to find out whether androgen receptors could be found in macrophages of female as well as male rat. It was also attempted to discover whether the macrophages of male and female mice show differences in term of androgen receptor.

\section{MATERIALS AND METHODS}

Preparation of resident peritoneal macrophages (Mф): Male and female Sprague-Dawley Rat (8W old) were killed by cervical dislocation and the peritoneal cells were extracted immediately by washing with 50 $\mathrm{ml}$ ice-cold PBS. Cells were kept at $2-8^{\circ} \mathrm{C}$ ice cold to avoid non specific attachment and were washed at $4^{\circ} \mathrm{C}$ for 2-3 times (1500 rpm for 5 minutes) with cold medium. Cells then counted and resuspended in complete RPMI 1640 medium.

Immunomagnetic method

The immunomagnetic method was used to capture macrophages for the receptor binding assay and to permit rapid washing of cells. Previously macrophages were obtained by allowing them to adhere to the plastic, however leaving the possibility of contamination by other cells. The immunomagnetic method, also simplified the separatation of the labelled cells from unbound steroid. Monoclonal antibody to Rat macrophages (Serotec) was used as first $\mathrm{Ab}$ and Dyna bead $\AA$ M-450 sheep anti IgG as a second Ab.

Macrophage isolation: Peritoneal macrophages were extracted as already described. Cells were kept on ice to avoid non-specific attachment. The anti Rat $\mathrm{M} \phi$ was diluted in 1/10 (as instructed) in complete medium. 50 $\mu \mathrm{l}$ of diluted $\mathrm{Ab}$ was used to label $5 \times 10^{6}$ cells (in a final volume of $0.2 \mathrm{ml}$ ). The heterogeneous cell suspension with the primary Ab was incubated for 3060 minutes on ice and gently vortexed every 5 minutes. Treated cells were collected by centrifugation at 2000 rpm for 10 minutes. The supernatant was discarded, the pellet resuspended and washed 2 times with Hank's balanced salt solution (HBSS), $\mathrm{PH} 7.4$ to remove unbound antibody.

The target cells then captured using Dyna-beads M-450 coated with sheep anti IgG. $7.5 \mu$ l of antibody coated Dyna beads M-450 ( 4x10 ${ }^{8}$ beads $\left./ \mathrm{ml}\right)$ was used to isolate $5 \times 10^{6}$ cells, as specified by Dynal. Cells were kept on ice for 20-30 minutes. For isolation, the test tubes were placed in the Dynal MPC-6 magnet and allowed to remain there for 2-4 minutes. During this time cells rosetted with immunomagnetic beads (Dynabeads M-450 coated with antibodies) were attracted to the wall of the test tubes by the magnetic field. The magnetic isolation was enhanced by occasional gentle shaking of the Dynal MPC-6. Supernatants were removed while the beads were held in place by the Dynal MPC-6. After discarding the supernatant, tubes were removed and HBSS solution added carefully along the wall of the test tubes, where the rosetted cells were attached. The cells resuspended gently and tubes reinserted in the Dynal MPC-6 washing repeated 5 times until the wash fluid was clear.

Receptor binding assay: Cells isolated as above were counted in a hemocytometer and diluted in the desired volume of complete medium. Cells in a volume of 0.2 $\mathrm{ml}\left(5 \times 10^{6}\right.$ cells $\left./ \mathrm{ml}\right)$ were placed in tubes and incubated for $1 \mathrm{~h}$ at $37^{\circ} \mathrm{C}$ with $1 \mathrm{mM}$ protease inhibitor (phenyl methyl sulfonyl fluoride, PMSF-Sigma Co.) and increasing concentrations $\left(2.5 \times 10^{-9} \mathrm{M}\right.$ to $\left.2.5 \times 10^{-8} \mathrm{M}\right)$ of the $\left[{ }^{3} \mathrm{H}\right]-5 \alpha \mathrm{DHT}$ with or without a one hundred foldexcess of unlabelled $5 \alpha$-DHT (to measure total and non specific binding respectively) (Amersham Co.). The use of protease inhibitor was based on a study by Sadi et $a l .{ }^{[43]}$ who showed that androgen receptor steroid binding was higher in the presence of a protease inhibitor. After incubation, tubes were replaced in the MPC-6 magnet as previously described washed 3 times with ice cold HBSS containing $0.1 \%$ (v/v) Triton $\mathrm{x}-100$ (Sigma Co.) and $1 \mathrm{mM}$ PMSF at $4^{\circ} \mathrm{C}$ to remove unbound steroid. Finally, the cells were resuspended in $100 \mu \mathrm{l}$ HBSS, transferred to a $5 \mathrm{ml}$ tube and $1 \mathrm{ml}$ scintillation fluid (ULTIMA GOLD TMMW Packard Company 6013159) added before transfer to the liquid scintillation counter.

Competition studies: Assay was performed to examine the binding of $17 \beta-\mathrm{E} 2$ and triamcinilone acetonide to androgen receptor of peritoneal M $\phi .5 \times 10^{6}$ cells/tube was incubated with $1 \times 10^{-9} \mathrm{M}\left[{ }^{3} \mathrm{H}\right]-5 \alpha \mathrm{DHT}$ in the presence of unlabelled competitors over the range of $1 \times 10^{-9} \mathrm{M}$ to $1 \times 10^{-6} \mathrm{M}$. Cells were then incubated at $37^{\circ} \mathrm{C}$ for $1 \mathrm{~h}$, washed 3 times with ice-cold HBSS containing $0.1 \%$ Triton $\mathrm{x}-100$ and $1 \mathrm{mM}$ PMSF using magnet as above. The percentage of binding inhibition by each concentration of competing ligand was determined in each case and compared with percentage inhibition induced by 100 fold DHT as reference for specific binding.

Statistical analysis: The results are expressed as the mean of experiments $(n=6) \pm$ the standard error (S.E) 
means or \pm the standard deviation (S.D) means. An unpaired student t-test was used to determine the probability ( $p$ ) of two sets of data from experiments being different from each other.

\section{RESULTS}

Saturation binding analysis over a wide range of $\left[{ }^{3} \mathrm{H}\right]-5 \alpha \mathrm{DHT}$ concentrations with whole cells separated magnetically revealed a straight line slope indicating high affinity for $\left[{ }^{3} \mathrm{H}\right]-5 \alpha \mathrm{DHT}$ in macrophages of both sexes. The Scatchard plots is shown in Fig. 1 and 2. The graph appears to indicate the presence of one type of binding site with a $\mathrm{Kd}$ of $3.3 \times 10^{-9} \mathrm{M}$ and $5 \times 10^{-9} \mathrm{M}$ for male and female macrophages respectively. The number of receptors per cell obtained in this study was $792 \pm 3$ for macrophages of male and $120 \pm 1$ for female rat.

Competition assay using $17 \beta$-estradiol and synthetic glucocorticoid triamcinolone-acetonide were performed to determine the nature of androgen binding sites in peritoneal macrophages (Fig. 3 and 4). These ligands did not inhibit specific binding, supporting our suggestion that the androgen binding was highly specific.

\section{DISCUSSION}

After showing the presence of androgen binding site in macrophages ${ }^{[44,45]}$, the next step was searching for sex differences in $\mathrm{Kd}$ value and the number of receptors. In this study the presence of an androgen binding species in rat macrophages has been identified and characterised. The reason that androgen receptors in macrophages have not been previously identified might be due to the method applied in the assay. The use of techniques normally employed for steroid hormone assays proved to be unsuccessful. These techniques included cytosol and whole cell radio receptor assay ${ }^{[14]}$ and also study involved experiments in which oil mixture (16\% mineral oil/ $84 \%$ silicon oil) was used in an attempt to separate bound from free steroid in non-activated peritoneal macrophages (unpublished data).

Data presented here demonstrated a specific androgen receptor in macrophages of both sexes. It was found that macrophages from male showed greater receptor in each cell and lower kd than equivalent cells from female. Thus, Fruhman,(46) reported that macrophages themselves might not be inherently different in males and females. However, this is in agreement to previous study in thymus by McCruden, ${ }^{[47]}$ who reported a higher binding capacity for androgen in females compared to males. Indeed, McCruden $^{[47]}$ suggested that higher androgen concentrations in male circulation would lead to a higher level of receptor occupancy in all androgen

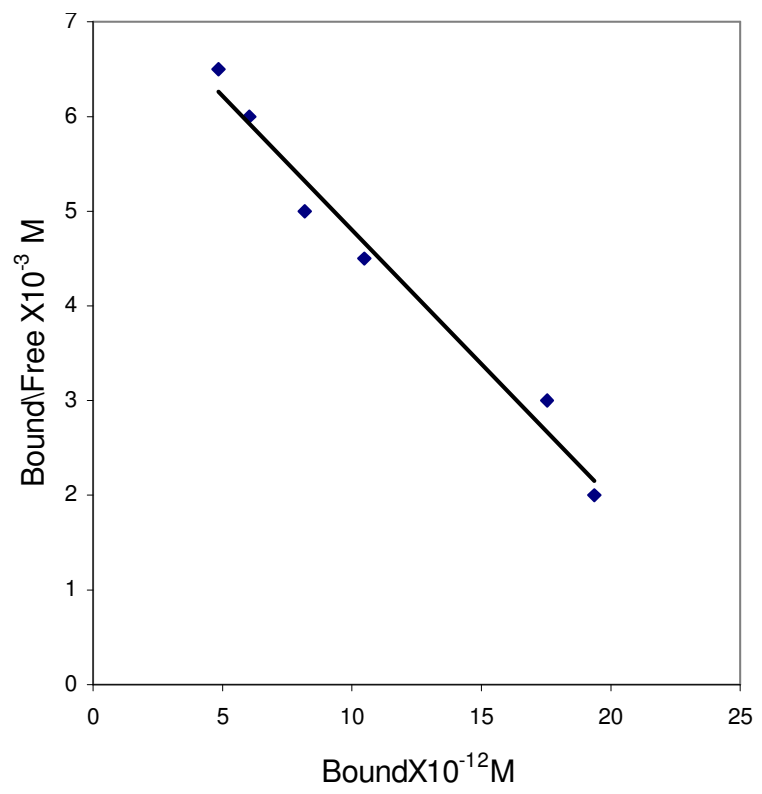

Fig. 1: Scatchard analysis of $\left[{ }^{3} \mathrm{H}\right]-5 \alpha \mathrm{DHT}$ binding to peritioneal macrophages of male SpragueDawley rat. $\left(\mathrm{kd}=3.3 \times 10^{-9}\right) \mathrm{M}$ and number of receptor/cell 792 \pm 3 )

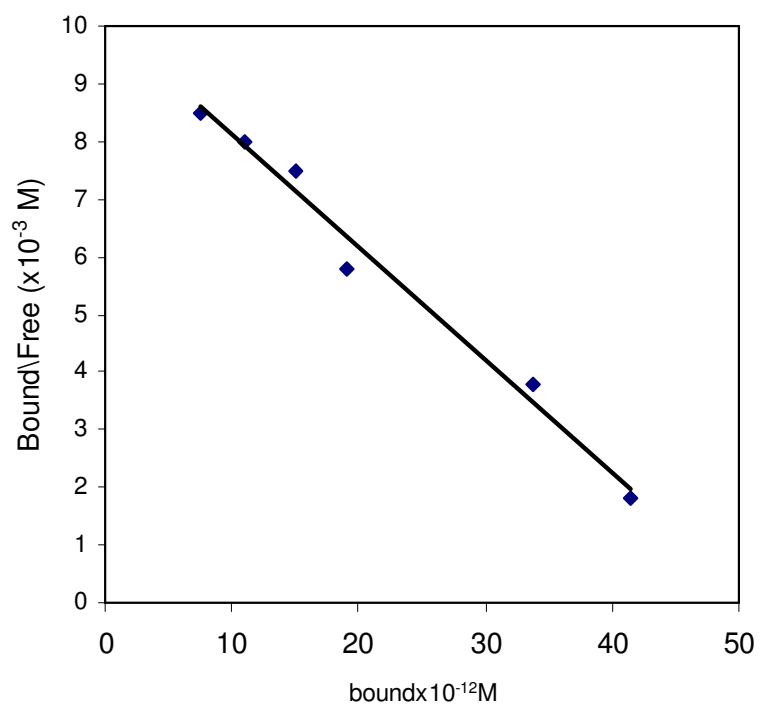

Fig. 2: Scatchart analysis of $\left[{ }^{3} \mathrm{H}\right]-5 \alpha \mathrm{DHT}$ binding to peritoneal macrophages of female SpragueDawley rat $\left(\mathrm{kd}=5 \times 10^{-9} \mathrm{M}\right.$ and number of receptor/cell 120 1 )

responsive tissue. This, in turn, would leave fewer cytosol receptor molecules available for radiolabelling in the assay. He also suggested that if female thymus possesses a high number of androgen and possibly a larger number of androgen responsive cells, therefore this might be important in the differences in immunological responsiveness between sexes. Moreover, greater expression of $\left[{ }^{3} \mathrm{H}\right]-5 \alpha$-DHT in male macrophage in this experiment is in agreement with study by McCrohon ${ }^{[7]}$, who stated greater expression of 


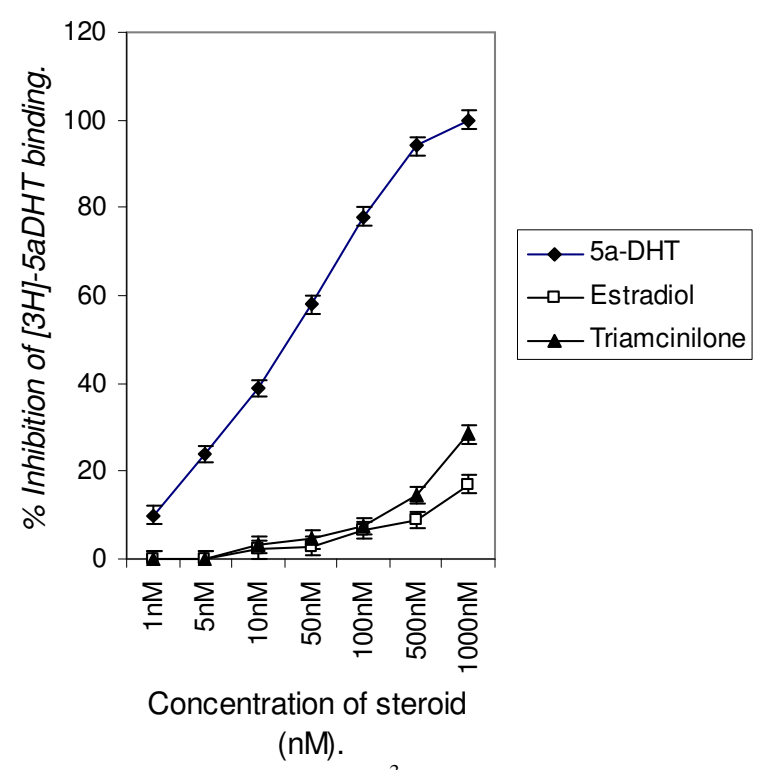

Fig. 3: Displacement of $\left[{ }^{3} \mathrm{H}\right]-5 \alpha \mathrm{DHT}$ binding by nonlabelled 5 $\alpha$-DHT, 17beta estradiol and triamcinilone acetonide (macrophages of male rat)

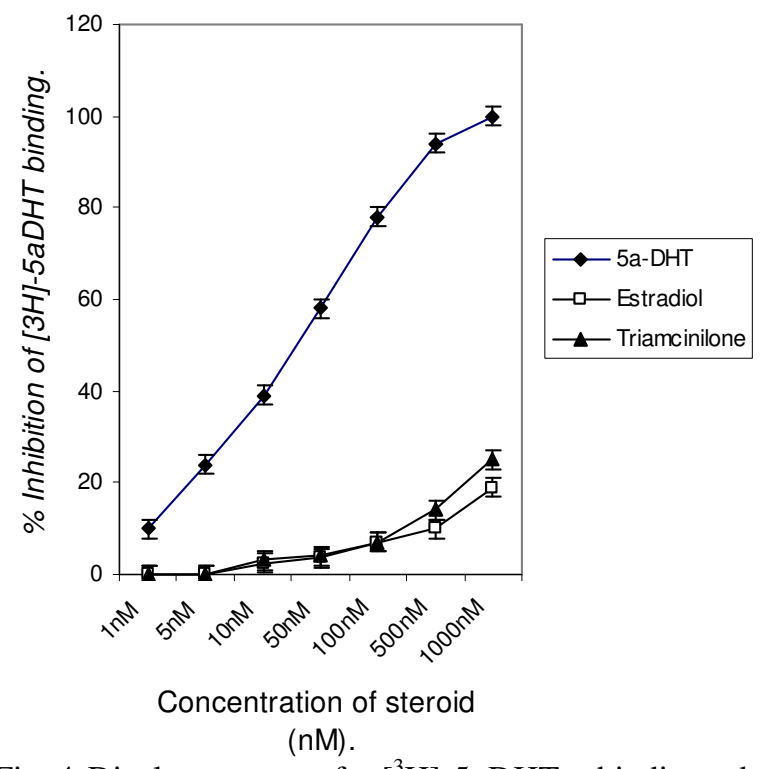

Fig. 4: Displacement of $\left[{ }^{3} \mathrm{H}\right]-5 \alpha \mathrm{DHT}$ binding by nonlabelled $5 \alpha$-DHT, 17beta esstradiol and triamcinilone (macrophages of female rat)

androgen receptor in macrophages of female donor than macrophages of male counterpart.

With regard to androgen receptor expression in macrophages of both sexes, Cutolo et al ${ }^{[27]}$ found that most males were positive for androgen receptor and most females were negative in a healthy population. Indeed, Cutolo et al. ${ }^{[27]}$ found no androgen receptors in the soluble fraction of synovial samples from healthy females, whereas androgen receptors have been shown in both the soluble and the nuclear fractions from female RA patient samples.
Meanwhile, Wang ${ }^{[41]}$ found no testosterone receptor in macrophages using RT PCR and Carruba ${ }^{[18]}$ reported that testosterone in contrast to estrogen do not have effect on apoptosis of U937 cells. However, it seems that androgen receptor detected here in macrophages might not be as classic receptor. Confirming our suggestion, Benten ${ }^{[48]}$ found no androgen receptor on cell line IC-21 and Raw 264.6 cells, but stated a rapid effect of androgen in macrophage that might be related to nongenomic pathway. It means that there is no intracellular and regular receptor but there is surface receptor which is coupled to phospholipase- $\mathrm{C}^{[49]}$. Recently, Wounder ${ }^{[50]}$ also demonstrated a nongenomic action of testosterone on macrophages ${ }^{[42]}$.

Immunomagnetic beads used in our experiments had two important implications; capturing peritoneal macrophages from other cells and also helping to separate labelled cells from unbound steroid. Results obtained by the binding assay using magnetic beads confirmed the results obtained in autoradiographic experiments in which specific binding for androgen in peritoneal macrophages was demonstrated ${ }^{[44]}$.

Scatchard analysis of receptor-binding data for androgens showed a straight line for peritoneal macrophages (Fig. 1 and 2). This indicates that there are androgen binding sites. It also indicates that $\left[{ }^{3} \mathrm{H}\right]-5$ $\alpha$ DHT binds to a single class of receptor with a high affinity and low capacity. It is, also in accordance with androgen receptor data in other tissues reported by other workers. The nature of androgen binding site in addition of sex differences in macrophage (Kd 3.3X10 ${ }^{9} \mathrm{M}$ and $5 \times 10^{-9} \mathrm{M}$ ) seems also to be different from other tissues. Gulshan et al. ${ }^{[14]}$ demonstrated the presence of two different estrogen binding species with $\mathrm{Kd}$ of $1.4 \times 10^{-10} \mathrm{M}$ and $3.3 \times 10^{-9} \mathrm{M}$ in rat peritoneal macrophages. These data suggest a difference in receptors found in different tissues.

The results obtained were highly significant and very much in accord with the results obtained by other workers of the differential effects of androgens on the macrophage and on the immune response in general. The number of androgen receptors found in macrophage of female rat is relatively low $(120 \pm 1)$ compared to the male (792 \pm 3 per cell) in these cells and also androgen receptors in human mononuclear leukocytes $(184 \pm 5)^{[16]}$. Moreover, with reference to competition experiment, it can be concluded that the binding identified in the rat macrophages is highly selective towards androgenic compounds. Little competition was seen from estradiol (17 $\beta$-E2) and synthetic glucocorticoid (Triamcinolone acetonide). It has been demonstrated that triamcinolone acetonide would competitively inhibit the binding of R1881 (synthetic androgen) to the progesterone receptor without blocking binding to the androgen receptor ${ }^{[51]}$.

This affinity of $5 \alpha$-DHT for androgen binding sites in peritoneal macrophage as well as the degree of 
relative binding affinities for various steroid hormones is comparable to the androgen binding sites in other cells ${ }^{[52-54]}$. These experiments are also comparable to work described by Kuhnle et al. ${ }^{[16]}$ who demonstrated high affinity (1.3 nM) androgen binding sites in peripheral mononuclear leukocytes (PML). While, genital skin fibroblasts characterised by a higher affinity for DHT than for testosterone, the binding affinities for DHT and testosterone were reported to be equal in human peripheral blood mononuclear leukocytes (PML) ${ }^{[16]}$.

In conclusion, it is conceivable from the findings reported in this study that the immunomodulatory action exerted by androgen and also sex differences in many disease might be at least partially realised through their interactions with respective receptors in macrophages. However, an interesting area remains to be investigated which could reveal a great deal of information on the central role macrophages play in the overall immune response. Also, further research on the androgen receptors in macrophage is required to establish whether the receptors are similar to the androgen receptor reported in other tissue or shows tissue variation as seen with estrogen ${ }^{[14]}$.

\section{ACKNOWLEDGEMENT}

The study was financially supported by ministry of health and medical education of Ir of Iran. Authors would also like to express appreciation to the people of department of Immunology, university of strathclyde.

\section{REFERENCES}

1. Davies, P., R.J. Bonney, J. Humes and F.A. Kuehl, 1982. The effect of anti-rhematic agents on macrophage function. Int. J. Immunopharmac., 4: 111-118.

2. Yamamoto, Y., H. Saito, T. Setogawa and H. Tomioka, 1991. Sex differences in host resistance to Mycobacterium marinum infection in mice. Infect. Immun., 59: 4089-96.

3. Nathan, C.F., 1987. Secretory products of macrophage. J. Clin. Invest., 79: 319-326.

4. Cutolo, M., M. Giusti, B. Villaggio, A. Barone, S. Accardo, A. Sulli, O. Granata, G. Carruba and L. Gastagnetta, 1997. Testosterone metabolism and cyclosporine a treatment in rheumatoid arthritis. Br. J. Rheumatol., 36: 433-9.

5. Posma, E., H. Moes, M.J. Heineman and M.M. Faas, 2004. The effect of testosterone on cytokine production in the specific and non-specific immune response. Am. J. Reprod. Immunol., 52: 237-43.

6. Qiao, Z., Z. Gue, G. Yin, L. Yin, J. Zhao and F. Wunderlich, 1999. Testosterone inhibits apoptosis of Leishmania donovani-infected macrophages. Zhangguo JI Sheng Chong Xue Yu Ji Sheng Chong Bing Za Zhi, 17: 21-24.
7. McCrohon, J.A., A.K. Death, S. Nakhla, W. Jessup, D.J. Handelsman, K.K. Stanley and D.S. Celermajor, 2000. androgen receptor expression is greater in macrophages from male than from female donors. A sex difference with implications for atherogenesis. Circulation, 101: 224-26.

8. Khalphali-Ellis, Z., R.J. Handa, R.H. Price Jr, B.D. Adams, J.J. Callaghan and M.H. Hendrix, 2002. Androgen receptors in human synoviocytes and androgen regulation of interleukin 1 Beta) IL-1 beta) induced Il-6 production: A link between hypoandrogenicity and rheumatoid arthritis. J. Rheumatol.. 29: 1843-46.

9. Khan, K.N., H. Masuzaki, A. Fujishita, M. Kitajima, I. Sekine, T. Matsuvama and T. Ishimaru, 2005. Estrogen and progesterone receptor expression in macrophages and regulation of hepatocyte growth factor by ovarian steroids in women with endometriosis. Hum. Reprod., 20: 2004-13.

10. Grossman, C.J., 1989. Possible underlying mechanisms of sexual dimorphism in the immune response, fact and hypothesis. J. Steroid Biochem., 34: 241-251.

11. Ahmadi-Renani, K. and A.B. McCruden, 1999. Five Alpha Dihydrotestosterone (5a-DHT) may modulate nitric oxide release via endogenous cytokines in peritoneal macrophages of NZB/BALBc mice. Med. J. Islamic Republic of Iran, 13: 207-211.

12. Stimson, W.H., 1988. Oestrogen and human Tlymphocytes: presence of specific receptors in the T-suppresor/cytotoxic subset. Scand. J. Immunol., 28: 345-50.

13. Danel, L., G. Souweine, J.C. Monier and S. Saez, 1983. Specific estrogen binding site in human lymphoid cells and thymic cells. J Steroid Biochem., 18: 559-63.

14. Gulshan, S., A.B. McCruden and W.H. Stimson, 1990. Oestrogen recptors in macrophages. Scand. J. Immunol., 31: 691-697.

15. McCruden, A.B. and W.H. Stimson, 1980. Androgen and other sex steroid cytosol receotors in the rat thymus. J. Endocrinol., 85: 47-48.

16. Kuhnle, U., U. Lindl, U. Keller, D. Armanini, M. Meurer and S. Baur, 1994. Androgen Binding sites in peripheral human mononuclear leukocytes of healthy males and Females. J. Steroid Bioch. Molec. Biol., 48: 403-408.

17. Stumpf, W.E.A. and M. Sar, 1976. Autoradiographic localization of estrogen androgen, progestin and glucocorticoid in 'target tissue' and 'non-target tissue'. In Receptors and mechanisms of action of steroid hormones. Edited by J.R. Pasqualini, pp: 41-84. Marcel Dekker.

18. Garruba, G., P. D'Agostino, M. Miele, M. Calabro, C. Barbara and G.D. Bella, 2003. Estrogen regulates cytokine production and apoptosis in PMA-differentiated, macrophage-like U937 Cells. J. Cell Biochem., 90: 187-96. 
19. Mondal, S. and L. Rai, 1999. Sexual dimorphism in phagocytic activity of wall lizard's splenic macrophages and its control by sex steroids. Gen Comp. Endocrinol., 116: 291-98.

20. Mondal, S. and U. Rai, 2002. In vitro effect of sex steroids on cytotoxic activity of splenic macrophjages in wall lizard (Hemidactylus flaviviridid). Gen. Comp. Endocrinol., 125: 264-71.

21. Lambert, K.C., E.M. Curren, B.M. Judy, D.B. Lubahn and D.M. Estes, 2004. Estrogen receptor alpha deficiency promotes increased TNF-alpha secretion and bacterial stimuli in vitro. J. Leukoc. Biol., 75: 1166-72.

22. Ahmadi, K. and A.B. McCruden, 1998. Sex differences in macrophage nitric oxide production. Iran. J. Med. Sci., 23: 42-47.

23. Ahmadi, R.K. and A.B. McCruden, 1997. Effect of $5 \alpha$-DHT on cytokine production by peritoneal macrophages of NZB/BALBc mice. Med. J. Islamic Republic of Iran, 11: 223-28.

24. Friedl, R., M. Bruner, T. Moeslinger and P.G. Spieckermann, 2000. Testosterone inhibits expression of inducible nitric oxide synthase in murine macrophages. Life Sci., 62: 417-29.

25. Ansar, A.S. and N. Talal, 1988. Sex Steroid, Sex Steroid Receptors and Autoimmune Disorders. In hand book of Steroid Receptors and Disease: Cancer, Autoimmune. Bone and Circulatory Disorders, pp: 289-316. Edited by Sheridan PJ. Blum K. Trachenberg MC, New York: Marcel Dekker Inc.

26. Cutolo, M., S. Capellino, P. Montagna, P. Ghiorzo, A. Sulli and B. Villaggio, 2005. Sex hormone modulation of cell growth and apoptosis of the human monocytic/macrophage cell line. Arthritis Res. Ther., 7: R1124-32.

27. Cutolo, M., S. Accardo and B. Villaggio, 1992. Evidence for the presence of Androgen receptors in the synovial tissue of rheumatoid arthritis patients and healthy controls. Arthritis and Rheumatism, 35: 1007-1015.

28. Mizuno, Y., T. Hosoi and S. Inoue, 1994. Immunocytochemical identification of androgen receptor in mouse osteoclast-like multinucleated cells. Calcified Tissue Intl. 54: 325-26.

29. Baranao, R.I., A. Tenenbaum and L.S. Rumi, 1991. Effects of sexual steroid hormones on the functionality of murine peritoneal macrophages. Steroids, 56: 481-85.

30. Chen, Q., H. Kaji, T. Sugimoto and K. Chihara, 2001. Testosterone inhibits osteoclast formation stimulated by parathyroid hormone through androgen receptor. FEBS Lett., 491: 91-23.

31. Suzuki, T., B.A. Murry, A.D. Darnel and H. Sasano, 2002. Progesterone metabolism in human Leukemic monoblast U937 cells. Endocrinology, 49: 539-46.
32. Colton, C.A., C.M. Brown and M.P. Vitek, 2005. Sex steroids, APOE genotype and the innate immune system. Neurobiol. Aging, 26: 263-72.

33. Castagnetta, L., O.M. Granata, A. Traina, L. Cocciadiferro, A. Saetta, R. Stefano, M. Cutolo and G. Carruba, 2002. A role for sex steroids in autoimmune disease: A working hypothesis and supporting data. Ann. N.Y. Acad. Sci., 966: 193203.

34. Ansar, A.S., W.J. Penhale and N. Talal, 1985. Sex hormones. Immune responses and autoimmune disease, mechanism of sex hormone action. Am. J. Pathol., 121: 531-51.

35. Stimson, W.H., 1987. Sex Steroid, Steroid Receptors and Immunity. In Hormones and Immunity. Edited by Berczi I and K. Kovacs, pp: 43-53. Lancaster: MTP Press.

36. Pelfrey, C.M., 2001. Sexual dimorphism in autoimmunity: a focus on $\mathrm{Th} 1 / \mathrm{Th} 2$ cytokines and multiple scerosis. Clin. Appl. Immunol. Rev., 1: 331-45.

37. Ansar, A.S. and N. Talal, 1989. Sex hormones and autoimmune rheumatic disorders. Scan. J. Rheumatol., 18: 69-76.

38. Ansar, A.S., M.J. Dauphinee and N. Talal, 1985. Effects of short-term administration of sex hormones on normal and autoimune mice. J. Immunol., 134: 204-210.

39. Grossman, C.J., 1985. Interactions between the gonadal steroids and the immune system. Science, 227: 257-261

40. Magdalena, B., 2000. Androgen and androgen receptor: Do they play a role in breast cancer. Med. Sci. Monit., 6: 433-38.

41. Wang, Y., L. Wang, J. Zhao and Z. Qiao, 2005. Estrogen, but not testosterone, down-regulates cytokine production in nicotine-induced murine macrophage. Methods Find Exp. Clin. Pharmacol., 27: 311-16.

42. Liva, S.M. and R.R. Voskuhl, 2001. Testosterone acts directly on CD4+ T lymphocytes to increase IL-10 production. I. Immunol., 167: 2060-67.

43. Sadi, M.V., P.C. Walsh and E.R. Barrack, 1991. Immunohistochemical study of androgen receptor in metastatic prostate cancer. Cancer, 67: 30573064.

44. Ahmadi, K. and A.B. McCruden, 2006. Macrophage may response to androgen via its receptor. Med. Sci. Monit., 12: 15-20.

45. Ahmadi, R.K. and A.B. McCruden, 1997. Androgen binding site in macrophages. Irn. J. Med. Sci., 22: 32-37.

46. Fruhman, G.J., 1973. Peritoneal macrophages in male and female mice. J. Reticulo. Endothel. Soc., 14: 371-377. 
47. McCruden, A.B. and W.H. Stimson, 1981. Androgen binding cytosol receptors in the rat thymus: Physicochemical Properties, Specificity and Localization. Thymus, 3: 105-117.

48. Benten, W.P., Z. Guo, J. Krucken and F. Wunderlich, 2004. Rapid effect of androgen in macrophages. Steroids, 69: 585-90.

49. Benten, W.P., M. Licherherr, O. Stamm, C. Wrehlke, Z. Guo and F. Wunderlich, 1999. Testosterone signalling through internalizable surface receptors in androgen receptor-free macrophages. Mol. Biol. Cell, 10: 3113-23.

50. Wunderlich, F., W.P Benten, M. Liecherherr, Z. Guo, O. Stamm, C. Wrehlke, C.E. Skeris and H. Mossman, 2002. Testosterone signallng in T cells an macrophages. Steroid, 67: 35-38.
51. Zava, D.T., 1979. Androgen receptor assay with $\left[{ }^{3} \mathrm{H}\right]$ methyl trienolone (R1881) in the presence of progesterone receptors. Endocrinology, 104: 10071012.

52. Grossman, C.J., P, Nathan, B.B. Taylor and L.J. Sholiton, 1979. Rat thymic dihydrotestosterone receptor: Preparation, Location and physiochemical properties. Steroids, 34: 539-53.

53. McCruden, A.B. and W.H. Stimson, 1991. Sex Hormones and Immune Function. In handbook of Psychoneuroimmunology (Sec. Edn.), pp: 475-93.

54. Kovacs, W.J. and N.J. Olsen, 1987. Androgen receptors in human thymocytes. J. Immunol., 139: 490-93. 